\title{
The limits of India's ethno-linguistic federation: understanding the demise of Sikh nationalism
}

\author{
By \\ Gurharpal Singh and Heewon Kim, SOAS University of London
}

\begin{abstract}
From 1984 until 1993, the Indian state of Punjab witnessed a sustained insurgency by Sikh militants campaigning for a separate sovereign state. This insurgency was ultimately defeated by the overwhelming use of security force that officially resulted in the deaths of 30,000 people. By the mid-1990s, a 'normalcy' had returned to Punjab politics, but the underlying issues which had fuelled the demand for separatism remain unaddressed. This paper examines critically the argument that India's ethno-linguistic federation is exceptional in accommodating ethno-nationalist movements. By drawing on the Punjab case-study, it argues that special considerations apply to the governance of peripheral regions (security, religion). Regional elites in these states struggle to build legitimacy because such legitimacy poses a threat to India's nation and state-building. In short, India's ethno-linguistic federation is only partially successful in managing ethno-linguistic demands in the peripheral Indian states.
\end{abstract}


This is the accepted version of an article that will be published by Taylor \& Francis in Regional and Federal Studies: http://www.tandfonline.com/loi/frfs20

Accepted version downloaded from SOAS Research Online: http://eprints.soas.ac.uk/25494/

\section{Introduction}

Measured by the experience of post-colonial states, federalism in India is relatively successful. Forged against division of the country in 1947, which created the dominions of India and Pakistan, it has stood the test of time, accommodating high levels of social and cultural diversity to evolve as a stable ethno-linguistic federation that today is a union of 29 states (Khilnani 1998; Suri 2016). This evolution has been managed, in the main, by the Indian National Congress (INC), which led the independence movement, and after 1947, skilfully balanced the pressures of governance and development under the guardianship of Jawaharlal Nehru, the country's first prime minister (1947-64). Although the federal design has been contested by groups and states unreconciled to the partition of the country, or opposed to the excessive centralisation - that often leads some to describe it as 'quasifederal' (Wheare 1946) - most analysts suggest that these challenges have been overcome by creative sub-national solutions, increasing political power at the centre of discontented groups, and a normative commitment to defeating secession at whatever cost (Adeney 2007; Capoccia et al. 2012). And if the Indian federation sometimes witnesses high levels of violence associated with secessionist movements, then these features, some argue, do not undermine the ethno-linguistic foundations of the union but can be explained by auxiliary factors; namely, the complex degree of ethno-linguistic heterogeneity in these units, political mismanagement by the centre (Adeney 2015: 19), ${ }^{i}$ the exogenous influence of external states, or inappropriate timing in the process of democratisation (Chadda 2000). The main narratives of Indian federalism insist that its blemishes are minor in contrast to its accomplishments (Kohli 2001).

In this paper we offer an alternative reading of federalism in India. We do so by arguing that its defining characteristics are to be found in the ethnic idea of India articulated by the INC during the constitution-making process (1946-9). This idea was anchored in Hinduism that was seen to transcend the conventional markers of ethnicity - language, caste, region, and tribe (Smith 1986) - and embodied the dominant nationalist sentiment within the Constituent Assembly (Bajpai 2011). This outlook was perfectly consistent with the idea of an ethno-linguistic federation within the mainstream heartland of India where 93 per cent of the country's 1.2 billion citizens live, but has been historically problematic in the peripheral 
This is the accepted version of an article that will be published by Taylor \& Francis in Regional and Federal Studies: http://www.tandfonline.com/loi/frfs20

Accepted version downloaded from SOAS Research Online: http://eprints.soas.ac.uk/25494/

regions - the borderland states in the north-west and north-east, most of which are populated by non-Hindu majorities, or have historically witnessed inflows of Hindu settlers (e.g. Bengalis in Tripura) from mainstream states. The argument is illustrated with special reference to the Sikhs of Punjab, and the rise and decline of a separatist movement in the state from the early 1980s to the middle of the 1990s. The paper ends with a more critical analysis of the limitations of India's ethno-linguistic federation in the peripheral states and the need to focus on why regional elites in these state struggle to build enduring legitimacy.

\section{The idea of India and India's federal design}

Although federalism can be a tool for accommodating ethnic and cultural diversity, it is difficult to disassociate the dominant ethnic group(s) in a state from the nature of federal design, or its role in maintaining the stability of the federation itself (O'Leary 2001). India is a case in point. The INC had committed itself to the linguistic reorganisation of provinces before independence, and restructured its own organisation on linguistic lines. But its idea of India as it evolved from the 1920s, in the Nehru Report (1928), in the INC's opposition to the Communal Award (1933), and the negotiations with the Muslim League before 1947, envisioned a highly centralised polity undergirded by socialism, secularism and planned economic development. In contrast, the Muslim League's vision of post-colonial India corresponded more to the Government of India Act (1935), as a subcontinent of provinces with strong consociational devices, with an option for a confederation for the grouping of majority Muslim provinces together. At the root of these basic differences was whether, as the Muslim League insisted, India was a multinational state, or as the INC argued, a multicultural one (Bhattacharyya 2001) with regional and cultural diversity that is cross-cut by an overlapping sense of unity (Adeney 2007). In the event, when Nehru rejected the Cabinet Mission Plan (1946), which went a long way to accommodating the Muslim League demands in a united India (Adeney 2002; Bhattacharyya 2010), this was ultimately the rock which broke the ship of India's unity. The INC secured a resized India but its price was Pakistan. The division eventually took place along religious lines, though both India and Pakistan retained significant minority religion populations (Talbot and Singh 2009).

Partition enabled the INC to craft India's constitutional and federal design in its own image. Officially, its vision drew inspiration from territorial civil conceptions of nationhood 
This is the accepted version of an article that will be published by Taylor \& Francis in Regional and Federal Studies: http://www.tandfonline.com/loi/frfs20

Accepted version downloaded from SOAS Research Online: http://eprints.soas.ac.uk/25494/

which sought to transcend the particularisms of caste, language, tribe, religion and region that characterised Indian society and had provided succour for imperial rule. But central to this vision was a celebration of India's ancient heritage as the descendent of a 'civilisation state' which had historically overcome regional and social particularisms. 'The diversity of India', Nehru wrote,

is tremendous; it is obvious; it lies on the surface and anybody can see it...Ancient India, like ancient China, was a world in itself, a culture and a civilisation which gave shape to all things...Some kind of a dream of unity has occupied the mind of India since the dawn of civilisation. That unity was not conceived as something imposed from outside, a standardisation of externals or even of beliefs. It was something deeper and, within its fold, the widest tolerance of beliefs and custom was practised and every variety acknowledged and even encouraged (Nehru 1989: 61-2, emphasis added).

This 'something deeper', which held the 'dream of unity' alive, had enabled India to overcome foreign conquest and maintain a social order. India's experience of 'three or four thousand years of cultural growth and continuity [was] remarkable': it could have taken place only if there was something in that culture 'which gave it the dynamic strength to do so, some inner vitality and understanding of life (Nehru 1989: 88). Although Nehru carefully avoided identifying this quality with Hinduism, he was also quite clear that for him it was rooted in 'culture or religion'. This 'culture or religion' was so pervasive that Christians, Jews, Muslims and Parsees 'never ceased to be Indians on account of a change of their faith' (Nehru 1989: 62). Nehru and the INC selected, rarefied and historicised the past in the name of 'non-nationalist nationalism'. An 'indissoluble connection' was established between Hinduism and Indian civilisation's tolerance (Vanaik 1997: ch. 4). But much of this construction of Indian history is borrowed directly from the work of German orientalists in the nineteenth century who celebrated the idea of Hindu tolerance embodied in the maxim that 'there are many levels of truth'. 'What follows from the assertion', as Embree notes, 'is not toleration; rather all truths, all social practices, can be encapsulated within the society as long as there is [a] willingness to accept the premise on which the encapsulation is based' (Embree 1990: 30). Encapsulation can - like the Ottoman millet system - facilitate accommodation, co-option, and eventually assimilation, but not political equality. It is, however, distinct from modern strategies of integration based on common citizenship, or forced assimilation, and is essentially a pre-modern strategy of accommodation for the threatening 'other' as an 'inferior' religious 'truth' (Embree 1990; McGarry and O'Leary 1993). 
This is the accepted version of an article that will be published by Taylor \& Francis in Regional and Federal Studies: http://www.tandfonline.com/loi/frfs20

Accepted version downloaded from SOAS Research Online: http://eprints.soas.ac.uk/25494/

Although India's constitution established a secular state, the constitution-makers legitimised a distinction between markers of identity that were politically acceptable - caste, region, language and tribe. In contrast, religious claims on public life from minorities, principally the demand for reservations for legislative seats based on religion, were rejected. However, in establishing this distinction the constitution makers conflated Hinduism with popular culture, adding an expansive definition of a Hindu to include Buddhists, Jains and Sikhs as well as all those who were not the designated religious minorities (Bajpai 2011; Kim 2015). ${ }^{\text {ii }}$ In this way, Hinduism attained the status of a 'meta-ethnicity' in which there was inclusion, accommodation and pluralism within the Hindu tradition because, as Gellner reminds us, "Hindus "speak the same language" even when they do not speak the same language' (Gellner 2006: 105). In other words, the pantheon of Hinduism can accommodate linguistic, caste, regional, tribal diversity and internal pluralism. In post-Independence India, these fault lines between the dominant culture of Hinduism, and the ethno-linguistic divisions within it, on the one hand, and non-Hindu religions, on the other, would become difficult to bridge in the peripheral regions in the northwest and northeast.

The experience of the predominantly non-Hindu peripheral regions since 1947 suggests that there is an argument for considering India as an 'ethnic democracy' (Peled 1992; Yiftachel 1992), ${ }^{\text {iii }}$ which combine 'the extension of political and civil rights to individuals and certain collective rights to minorities with institutionalised dominance over the state by one of the ethnic groups' (Smooha 1990: 391). Whereas in some ethnic democracies the process of 'institutionalisation' is formal and explicit, in others it is informal and implicit. In India the 'institutionalisation of dominance' would appear to derive from unspoken assumptions about state secularism and 'civilisational essence', the historic ascendency of the INC in fashioning the post-1947 state in its image, and the existence of Hindu majoritarianism. ${ }^{\text {iv }}$ Thus, though the minorities have been granted individual and, in some cases, collective rights, the recognition of these rights has been based on a tactical accommodation with hegemonic Hinduism. ${ }^{\mathrm{v}}$

\section{Creating a strong centre}


This is the accepted version of an article that will be published by Taylor \& Francis in Regional and Federal Studies: http://www.tandfonline.com/loi/frfs20

Accepted version downloaded from SOAS Research Online: http://eprints.soas.ac.uk/25494/

From the 1920s the INC advocated a strong centre to ensure the country's unity. This commitment arose from a rejection of colonialism's characterisation of India as a mere geographical expression which had been united by British rule. Whereas many within the Muslim majority regions argued that India should be a land of the provinces, with a weak coordinating centre, for the INC this represented a recipe for Balkanisation, a divided subcontinent that would forever remain subject to imperial intervention and intrigue. Partition and its bloody aftermath therefore provided the ideal opportunity for the INC to create a centralised state. Nehru and a section of the party leadership had for some time supported this policy with 'a great deal of unitary control' (Austin 1966: 189), but in the unique conditions of post-independence - the violence of partition, rebellious princely states and the weakness of the party in the peripheral states - this proposal encountered little opposition. Even before the violence of partition, within a few days of the announcement of the 3 June 1947 Plan to divide India, the Constituent Assembly resolved to construct a constitution that would be 'federal with a strong centre', and an 'indestructible union' (Austin 1966: 193) that would be both 'unitary as well as federal according to the requirements of time and circumstance' (Austin 1966: 188). States did not have an entity prior to the union: they were functional, subordinate and subject to modification of size by the centre. Dr Ambedkar, in introducing the draft constitution, was at pains to dispel any lingering doubts:

\begin{abstract}
...though India was to be a federation, the federation was not the result of an agreement by the States to join the federation, and that the federation not being the result of an agreement, no State has the right to secede from it. The federation is a Union because it is indestructible. Though the country and the people may be divided into different States for convenience of administration, the country is one integral whole, its people a single people living under a single imperium derived from a single source. The Americans had to wage a civil war to establish that the States have no right of secession and that their federation was indestructible. The Drafting Committee thought that it was better to make it clear at the outset rather than to leave it to speculation or to disputes (Commission on Centre-State Relations 1988: 9).
\end{abstract}

The new constitution based on the principle of an ethno-linguistic federation provided broad protection for cultural and linguistic minorities within states. ${ }^{\mathrm{vi}}$ However, states could be abolished, reorganised and their powers curtailed without a significant constitutional threshold. The division of powers between the centre and the states was heavily weighted in favour of the former. ${ }^{\text {vii }}$ Article 356 allowed for the takeover of the administration of any state in the Union by central government in case the governor of the state reported that 'the government of the State cannot be carried on in accordance with the provisions of the 
This is the accepted version of an article that will be published by Taylor \& Francis in Regional and Federal Studies: http://www.tandfonline.com/loi/frfs20

Accepted version downloaded from SOAS Research Online: http://eprints.soas.ac.uk/25494/

constitution'. And to these considerable powers of the centre were added emergency provisions (Article 352) which gave the centre broad remit in dealing with the states and the right to suspend the normal functioning of the constitution. In addition, residual powers were invested in the centre. For some analysts these provisions made India a 'quasi-federal', or a 'unitary' state (Morris-Jones 1987).

\section{Indian federalism and governance in the peripheral regions}

India's federal design has been most successful in the mainstream Hindu heartlands where, notwithstanding ethno-linguistic diversity, the principle of reorganising federal units along linguistic lines has become firmly established. When the demands arose for the linguistic reorganisation of internal colonial boundaries in the 1950s, the centre eventually (and reluctantly) followed four guidelines for regulating ethnic conflicts, as set out by Paul Brass. First, no secessionist movements were to be tolerated; where necessary they would be supressed by force. Second, given the commitment to a secular state, 'no demand for political recognition of a religious group would be considered'. Third, 'no capricious concessions would be made to the political demands of any linguistic, regional or other culturally defined groups'. Finally, 'no political concessions to cultural groups in conflict would be made unless they had demonstrable support from both sides in the conflict' (Brass 1991: 168). By and large, these guidelines worked reasonably well in the Hindu heartlands.

In contrast, in the peripheral regions in the northwest and the northeast, special considerations have always applied. Although Jammu and Kashmir is governed by Article 370 of the constitution, which ostensibly gives it special autonomy, the provisions of this article have been seriously eroded (Bose 2003). In the 1950s and early 1960s, the campaign for a Punjabi-speaking state by the Shiromani Akali Dal ((SAD) the main Sikh political party) was firmly opposed on the grounds that it was a cover for a religious demand (Nayar 1966); it was only conceded after the SAD clearly articulated the demand in linguistic terms. In the northeast, a heterogeneous region beset with internal and anti-national conflicts, the centre has used a variety of approaches - counterinsurgency tactics, the creation of new states, sub-state autonomy and the creation of special zones - to reorganise internal boundaries (see Adeney and Bhattacharyya in this special issue). Because of the heterogeneity of the region these concessions and reorganisations have commanded only varying degrees of legitimacy, frequently resulting in high levels of localised violence 
This is the accepted version of an article that will be published by Taylor \& Francis in Regional and Federal Studies: http://www.tandfonline.com/loi/frfs20

Accepted version downloaded from SOAS Research Online: http://eprints.soas.ac.uk/25494/

(Baruah 2010). In both the northwest and the northeast, India's ethno-linguistic federation continues to be tested to the limit.

Adeney's Table 4 highlights the intensity of conflicts in these regions (Adeney 2017). The PRIO database classifies many of these conflicts as a 'war'. In Kashmir, for example, some organisations claim that since 1990 over 100,000 people have been killed, 10,000 have disappeared and up to 15,000 have been detained without trial. In 2011, the Jammu and Kashmir state government put the figure killed since the onset of the conflict in 1989 at 43,460 (Nandal 2011). Furthermore, 150,000 Kashmiri Hindus have fled the valley to settle in the Hindu majority region of Jammu. Similarly, in Punjab nearly 30,000 people were killed in the separatist and counterinsurgency violence between the early 1980s and 1993; the number of involuntary disappearances and those detained illegally has been variously estimated between 20,000 and 45,000 people (Thandi 1996: 165). Data on ethnic violence in the northeast presented in Adeney and Bhattacharyya's contribution to this special issue demonstrate the high level of violence, despite the smaller population of these states.

High levels of violence in the peripheral regions have been managed by the use of paramilitary forces and the Indian army. Although these regions are the sites of India's borderlands with hostile neighbours, the level of securitisation is exceptional. According to some estimates there are 500,000 military and paramilitary personnel in Kashmir (Swami 2014). At the peak of counterinsurgency operations in Punjab in the early 1990s, 250,000 military and security personnel were deployed against the Sikh militants; and like Kashmir, Punjab is home to frontline military cantonments and security bases that can be mobilised for internal as well as external security. Similarly, in the northeast the Indian army has been engaged in constant warfare against insurgents since 1947 (Franke 2009), but the 1962 IndoChina war led to a major extension of the security architecture in the region to deal with internal and external threats (Maxwell 1972). This securitisation, however, has also been accompanied by the use of special legislation such as the Armed Forces (Special Powers) Act (AFSPA) (1958), which enables the governor of a state to declare areas in the state as 'disturbed' and empowers the armed forces to 'exercise special powers'. Such legislation gives wide immunity to security forces to suppress insurgencies in the peripheral regions and has been used alongside other special measures such as Terrorist and Disruptive Activities (Prevention) Act (1987) and Prevention of Terrorism Act (2002) (Mohapatra 2004). As 
This is the accepted version of an article that will be published by Taylor \& Francis in Regional and Federal Studies: http://www.tandfonline.com/loi/frfs20

Accepted version downloaded from SOAS Research Online: http://eprints.soas.ac.uk/25494/

Adeney and Bhattacharya's interview data in this special issue makes clear, the use of the AFSPA remains controversial in the region.

This high level of violence is often accompanied by the suspension of federal governance and the imposition of central rule from Delhi under President's Rule. Although the frequency of President's Rule in the peripheral regions is not too dissimilar from mainstream states - which, because of their size and numbers, are prone to political instability - what distinguishes it are the reasons and duration. Thus, Punjab for instance, has witnessed the highest frequency of President's Rule since 1947 (Adeney 2007: 116) and the longest period (from June 1987 to February 1992) following the rise of Sikh militancy. Jammu and Kashmir was under President's Rule for almost six years (from January 1990 to October 1996), with regular periods of central rule since 2002 as power-sharing local state governments have faltered. Assam witnessed four prolonged periods of central rule from December 1979 to June 1991, mostly in connection with inability of the state government to manage ethnic violence. Other states in the north-east (Manipur, Meghalaya, Nagaland, Tripura, and most recently, Arunachal Pradesh), have also come under direct rule from Delhi. viii

Such suspensions of state governance amidst ethnic conflict are sometimes followed by election boycotts or 'khaki elections'. National elections were boycotted in Jammu and Kashmir in 1989, 1998 and 1999; state elections were boycotted in 1996 (Bose 2003). At the height of separatist violence and counterinsurgency operations the state elections in Punjab in 1992 were boycotted by the SAD (Singh 2000: ch. 9). The main regional parties in Assam refused to participate in the polls in 1983 and Nagaland in 1998, enabling the Congress to win all 53 of the 60 assembly seats unopposed. The National Socialist Council of Nagaland, which has influence in Nagaland and Manipur, boycotted the state elections in the latter and the 2004, 2009 and 2014 national elections, requiring re-polling in some districts (Singh 2009: 345-7). The high security presence of the military and paramilitary forces in these states combined with the regular disengagement of the main regional political parties frequently enables national parties such as the Congress or the BJP to capture most of the votes and seats in these regions in national elections. ${ }^{\text {ix }}$ 
This is the accepted version of an article that will be published by Taylor \& Francis in Regional and Federal Studies: http://www.tandfonline.com/loi/frfs20

Accepted version downloaded from SOAS Research Online: http://eprints.soas.ac.uk/25494/

Finally, the weak legitimacy of India's ethno-linguistic federation in the peripheral regions is further demonstrated by the frequency with which the centre has to engage in negotiating peace accords. These 'accords', 'peace agreements', 'memoranda of understanding' are utilised at the state or sub-state levels, and vary in their symbolic significance from aiming to settle long-term conflicts, for example, the Naga Peace Accord (2015), to the Memorandum of Settlement (2003), which created the Bodoland Territorial Council in Assam (Bhaumik 2015; Das 2005). Most of the states have a long history of regional agreements that were either unimplemented by the centre or used for political advantage (Singh 2000: 103), thereby repeatedly fuelling the feeling of resentment that the centre has been disingenuous in negotiate such agreements only to renege soon after the agreements have been reached. Yet the political domestication of former rebels has rarely provided an enduring solution, resulting in constant alternation between conflict and precarious stability. Since 1947, the history of Assam, Mizoram, Nagaland, Tripura and Manipur is littered with accords with New Delhi; ${ }^{\mathrm{x}}$ in Punjab, as we shall see below, much of the resentment which fuelled separatist violence in the 1980s and 1990s was due to the failure of New Delhi to deliver on the Rajiv-Longowal Accord (1985).

\section{Punjab and the Sikhs}

The qualitative and quantitative evidence of the precarious foundations of India's ethnolinguistic federation in the peripheral regions can be better illustrated with an in-depth state case-study. The Sikhs of Punjab are a distinctive ethno-national community defined by religion, language and ties with the historical province of Punjab (Grewal 1998; Pettigrew 1995). Like all such communities, Sikhs are divided by class and caste, with Dalit Sikhs constituting almost one-third of the community, and traditionally politically aligned with Congress or Dalit parties in opposition to Jats (farming caste) who make up nearly two-thirds of the Sikh population and have generally supported the SAD, though this allegiance has, at times, alternated with the Congress, particularly in post-1947 Punjab where the Congress has been the dominant party (Singh and Tatla 2006). Social pluralism among Sikhs and Congress's strategy as a catch-all party frustrated the emergence of a more militant strain of Sikh nationalism until the early 1980 s, but at the same time the community's religious and cultural heritage suggests that modern Sikh identity is remarkably cohesive having its roots in a Jat- dominated ethnie, a sacred text and religious tradition dating from Guru Nanak, the 
This is the accepted version of an article that will be published by Taylor \& Francis in Regional and Federal Studies: http://www.tandfonline.com/loi/frfs20

Accepted version downloaded from SOAS Research Online: http://eprints.soas.ac.uk/25494/

founder of the faith in the fifteenth century (Shani 2008). As we shall see below, under conditions of political closure in Punjab between 1984 and 1997, when the normal political process in the province was largely suspended as result of the Indian army's entry into the Golden Temple in June 1984, it was this political identity which assumed political prominence.

In pre-partition Punjab the Sikhs held the balance of power between Muslim and Hindu political representation in the province and were equally dispersed between West and East Punjab. The community's opposition to Pakistan led its political leadership to seek special guarantees within the Indian union which were rebuffed, resulting in the Sikh representatives in the Constituent Assembly refusing to sign the constitution. After 1947, the SAD initially campaigned for a Sikh province, but then sought the linguistic reorganisation of Punjab as a Punjabi-speaking area. Opposition to this campaign was led by the INC that mobilised the majority Punjabi Hindu population to declare Hindi as its mother tongue, and thereby frustrated the numerical case for a Punjabi-speaking province (Brass 1974). A Punjabi-speaking state was eventually conceded in 1966, but after the India-Pakistan war (1965). However, the reorganisation left so many issues - the status of Chandigarh, sharing of river waters, and the exclusion of Punjabi-speaking territories - unresolved that it soon led to an autonomy movement organised by the SAD around the Anandpur Sahib Resolution (ASR, 1973) that, among other demands, called for New Delhi's powers to be limited to currency, defence, communications and external affairs as well calling for an area where Sikhs could live in freedom and exercise their hegemony. The Dharam Yudh Morcha launched by the SAD in 1982, and the reluctance of the prime minister Indira Gandhi to reach a negotiated settlement, precipitated the events that led to Operation Blue Star in which the Indian Army stormed the Golden Temple in June 1984, resulting in 1,000 deaths in the complex and the subsequent assassination of Prime Minister Indira Gandhi. This was followed by the revenge killings of Sikhs in New Delhi in which nearly 3,000 people died. Some of these pogroms were organised by Congressmen from Delhi who would subsequently assume senior positions within the party (see Jeffrey 1994; Singh 2006; Tully and Jacob 1985). 
This is the accepted version of an article that will be published by Taylor \& Francis in Regional and Federal Studies: http://www.tandfonline.com/loi/frfs20

Accepted version downloaded from SOAS Research Online: http://eprints.soas.ac.uk/25494/

These developments led to the rise of a militant wing within the Sikh diaspora and terrorist actions resulting in the downing of the Air India flight off the coast of Ireland in 1985. In order to restore normalcy the Congress government negotiated the Rajiv-Longowal Accord of 1985, which seemingly dealt with the religious, political, economic and territorial demands of the SAD, including territorial, river waters and the transfer of Chandigarh to Punjab (See Singh 2000: chp.8) The accord was followed by state elections that brought the SAD to power. However, within a year the centre refused to implement the key provisions of the Accord, principally the transfer of Chandigarh to Punjab, and the moderate SAD government was gradually undermined by Sikh militants and then dismissed by President's Rule in June 1987 (Singh 1991). Coercive measures had been used in Punjab in the 1950s and 1960s, but what distinguished the 1980s, with the failure of Rajiv Gandhi to re-establish some degree of political normalcy, was the extent to which the central governments were prepared to use force to crush Sikh separatism. At the height of the insurgency in the early $1990 \mathrm{~s}$, almost a quarter of million military and paramilitary forces were engaged in counterinsurgency operations against groups campaigning for a separate Sikh state. These militant groups were not without significant support: in the 1989 national elections, their representatives or supporters won 10 of the 13 parliamentary seats from Punjab and captured the majority of popular support; and in June 1991, if the newly elected national Congress government had not postponed the state poll, the militants would certainly have won the assembly elections (Singh 2000: ch.9). In the event, the Congress held 'khaki elections' in February 1992. These were boycotted both by the militants and the SAD. The boycott resulted in a Congress victory (on a turnout of 24 per cent) that was used as a pretext to intensify the war against separatism. By the end of 1993, most leading militants and their organisations had been eliminated, the moderates had been muzzled, and Punjab was being hailed as a 'model' for combating separatism (Singh 2000: chps 9 and 10).

The overwhelming use of force against Sikh militants and moderates between 1984 and 1993 highlights the determination of the Indian state to defeat Sikh ethno-nationalism. It also illustrates how the parameters for autonomy are narrowly circumscribed to what is acceptable within the constitution. 'Normalcy' in this instance - as in most political movements in the peripheral regions - necessitates forgoing political demands, such as greater autonomy, or calls for the limitations on the centre's powers, in exchange for political 
This is the accepted version of an article that will be published by Taylor \& Francis in Regional and Federal Studies: http://www.tandfonline.com/loi/frfs20

Accepted version downloaded from SOAS Research Online: http://eprints.soas.ac.uk/25494/

power at the regional level: it is a response that accommodates ethnic regional elites but requires them to regularly disarticulate cultural and ethnic demands deemed unacceptable under the constitution. In the case of the Sikhs, the predominant nationalist discourse was that the ASR was a secessionist document because not only did it call for a reordering of India's centre-state relations, but also spoke of a region where Sikhs could exercise 'hegemony' (Government of India 1984).

Since 1997, the SAD has been in power in Punjab for 15 years in alliance with the BJP. Although it is formally committed to the ASR, its coalition with the BJP is predicated on the SAD disarticulating Sikh ethnic demands. Thus, during the first post-militancy SADBJP government (1997-2002), though the party fought the election on a manifesto of prosecuting security officers guilty of human rights violations, once in power its leader declared that his government would take 'an even-handed approach and let the law take its course' (Kumar 2008; Ramesh 1997). The SAD gradually distanced itself from Sikh ethnonationalist claims to be the champion of Punjabiyat, an overarching loyalty to Punjab regionalism in the interests of communal harmony, economic development and maintaining law and order (Chima 2015). Probably because it was in a coalition government at the centre, the leadership of SAD steadfastly refused to raise the religious, political, economic and territorial demands that had led to the autonomy movement in the early 1980s.

The second period of governance of the SAD-BJP coalition (from 2007-17) has also been characterised by malgovernance, corruption and the use of patronage within Sikh institutions to disarticulate and manage Panthic (the Sikh community's) religious and political demands. Such politics of cultural containment have ostensibly fostered not only repeated forms of ethnic negation marked by reluctance to address the causes and consequences of Operation Blue Star but also malgovernance, including fiscal irresponsibility (Dhillon 2006). This is because populist measures, such as free electricity for farmers and over recruitment into state employment, have been used to build the SAD's political base in the absence of delivering on the ethno-national demands, resulting in the doubling of the state's debt burden to over 30 per cent of the state's Gross Domestic Product (GDP). Currently, 21 per cent of the state's revenue receipts are used to pay debt repayments, and in the 2014-15 financial year, 70 per cent of the new debt is being used for repayment of the outstanding debt (Dhaliwal 2015). The debt overhang is so pervasive that the state 
This is the accepted version of an article that will be published by Taylor \& Francis in Regional and Federal Studies: http://www.tandfonline.com/loi/frfs20

Accepted version downloaded from SOAS Research Online: http://eprints.soas.ac.uk/25494/

government has often struggled to pay the salaries of its officials and has resorted to offbudget sales to cover the shortfall. Additionally, the political leadership of the SAD has become embroiled in high profile corruption cases, with allegations that it has nurtured a crony business culture as well as abetted the widespread epidemic of drug abuse in the state (Nilanjan 2015). The degree of disenchantment of the electorate with the SAD was partly reflected in the May 2014 national elections when the new Aam Aadmi Party (the People's Party) won 4 of the 13 seats from Punjab and the SAD, Congress and the BJP secured 4, 3, and 2 seats, respectively (The Indian Express 2014). Indeed, the SAD came close to being electorally wiped out in the latest Punjab Legislative Assembly Elections (February 2017) in which it secured only 20 seats along with the BJP (Singh 2017).

The SAD has also used Sikh religious institutions and their resources to emasculate potential challenges to its legitimacy (Chima 2015). The first challenge was broad resentment within the Sikh clergy of blasphemous practices by new religious movements with a popular following among Scheduled Castes who comprise 32 per cent of the state's population, and significant numbers at the margins of Sikhism and Hinduism who follow heterodox practice, or have evolved their own distinctive religious doctrines. The SAD disarticulated this resentment by insider deals with leaders of new religious movements and by buying off elements of the Sikh clergy (Singh 2012). The second concerned the demand for the release of political prisoners from the insurgency period. When there was significant mobilisation for the release of these prisoners, the SAD undertook covert operations to discredit the campaign that had gathered widespread momentum within Punjab and the Sikh diaspora (Chima 2015). The third, and most serious, occurred between September and November 2015 in incidents of desecration of the Guru Granth (the Sikh holy book). Wholesale mobilisation by the Sikh populace led to a virtual standstill in Punjab. While the Sikh religious authorities sought to give vent to the anger and dismay at these incidents felt by the Sikh community, their mobilisation was countered by the SAD through its control of Sikh religious institutions which placed them at odds with popular sentiment, leading to well-publicised splits within the Sikh clergy and the committee which manages Sikh Shrines - the Shiromani Gurdwara Prabandhak Committee (Ahmed 2015; Jain 2015). Not unexpectedly, today the SAD's claim as the premier representative of the Sikh community is severely damaged. In a situation reminiscent of the 1980s and 1990s, when the SAD failed to deliver on the ASR, it stands to be outflanked by more militant organisations that are waiting on the wings. 
This is the accepted version of an article that will be published by Taylor \& Francis in Regional and Federal Studies: http://www.tandfonline.com/loi/frfs20

Accepted version downloaded from SOAS Research Online: http://eprints.soas.ac.uk/25494/

Finally, the trauma of the events of the 1980s and 1990s persists in the collective consciousness of the Sikh community but the political demands that led to these events remain largely unaddressed. Nor has there been an official process of healing and reconciliation within the state. Under appropriate conditions, therefore, the claims of Sikh nationalism can re-emerge and readily undermine the contingency of the current social and political order and 'how it conceals its own impossibility' (Edkins 2003: 5). In the rapid changes that are now affecting the Sikhs of Punjab - the collapse of the agrarian economy, the assimilative pressures of the BJP sponsored Hindutva project (Jaffrelot 1996), the decline in the legitimacy of Sikh political and religious institutions, the rise of new religious movements at the boundaries of Sikhdom among Scheduled Castes and other socioeconomically disadvantaged castes, and rampant corruption - it would be premature to rule out a more strident assertion of Sikh separatism in the future. As the historical experience of the politics of cultural containment in the peripheral regions illustrates, either through coopted indigenous regional elites, or the exercise of force, 'normalcy' is regularly punctuated with periods of high levels of violence.

\section{Conclusion}

The 'strange' death of Sikh ethno-nationalism in mid-1990s needs to be understood against Indian state strategy to defeat separatism. It does so through a combination of extreme force and the accommodation of political elites in the peripheral regions where they abjure political demands in return for regional power. The use of force to manage, or eliminate ethnonationalist movements in the periphery, is a highly developed strategy that is brought into play when regional political elites either oppose the centre's rule or regularly exhaust their legitimacy and are outflanked by more militant political formations. The post-1947 statecraft of Indian nation-building is so well established that further reorganisation of mixed populations in these regions is unlikely to reduce the levels of conflicts. It has also promoted what Lancina (2015) calls the 'periphery versus periphery' to undermine the movements for separatism within the Indian union. Analytically, therefore, we need to develop a more critical perspective that reflects the history and evidence of the peripheral regions. 
This is the accepted version of an article that will be published by Taylor \& Francis in Regional and Federal Studies: http://www.tandfonline.com/loi/frfs20

Accepted version downloaded from SOAS Research Online: http://eprints.soas.ac.uk/25494/

Jammu and Kashmir, Punjab, the north-eastern states have tested the limits of India's ethno-linguistic federation. These regions have many

....aggrieved sections of [Indian] society with a long list of grievances against the centre, deeply resentful of the latter's encroachment of their political autonomy and democratic civil rights. In different ways and to varying degrees, they have desisted from taking part in the orthodox nationalist discourse (Sathyamurthy 1997: 718)

Before 1947 these regions were mostly outside the influence of the INC and were controlled by regional parties which did not share the former's vision of post-colonial India. At independence some of these regions were coerced into the Indian union or became the battle ground of ethnic cleansing associated with partition. Since 1947, some of these states have been the sites of Indian nation and state-building failure, maintaining a degree of resistance to these processes which have consumed an inordinate amount of the Indian state's scare resources. These states, moreover, are often populated by non-Hindu ethnic group majorities (Jammu and Kashmir, Punjab, Nagaland, Arunachal Pradesh, Meghalaya), or Hindu Bengali mainland settlers who have turned the 'sons of the soil' into a minority (Tripura and Manipur), or still, a revival of regional ethnic identity pre-dating the conversion to Hinduism (Assam). Finally, these territories are also distinctive in that they form the external border of the Indian state - a border which have been the site of several wars - that have sacralised the territory of the union within inner core of Indian nationalism.

India's commitment to its post-1947 borders has led to the quasi-militarisation of the peripheral regions punctuated with periods of tenuous 'normalcy'. Because these regions, or the states within them, command few political resources ( 7 per cent of the population and 8 percent representation in Parliament), as expanded on in reference to the northeast by Adeney and Bhattacharya in this special issue, their demands are rarely articulated at the regime level. Mostly because Nehru and other INC elites were exceptionally successful in using the partition to embed beliefs about the new state's borders, the mere questioning of these beliefs became synonymous with subversion. Indeed, after the Indo-China war (1962) the Sixteenth Constitutional Amendment Act (1963) was passed making the questioning of India's territorial integrity and unity a criminal offence and requiring all state and national legislators to swear an allegiance to India's unity. In sum, the autonomy and self-determination movements in the peripheral regions regularly contest the ambiguous reality of India's ethno- 
This is the accepted version of an article that will be published by Taylor \& Francis in Regional and Federal Studies: http://www.tandfonline.com/loi/frfs20

Accepted version downloaded from SOAS Research Online: http://eprints.soas.ac.uk/25494/

linguistic federation. In so doing, they provide a critical counterpoint to the relative 'success' of Indian democracy and its federation.

'Arguably the greater social, cultural, religious and linguistic diversity of these regions poses challenges for Indian federalism that are less obvious than in other states (Adeney 2015). This is certainly the case in the north-east, but not in the north-west. The salient cleavage in both regions, however, is that of religion; namely, most of these states have non-Hindu majorities. Religion, exceptional ethnic diversity, and the legacy of partition/independence (Jammu and Kashmir, Punjab, Assam, Nagaland), has tested the ethno-linguistic principles of Indian federalism so that alternative modes of accommodation e.g. Article 370 of the Indian Constitution which grants special status to Jammu and Kashmir, have been evolved. It also needs to be stressed that the two regions command only 7 per cent of India's 1.2 billion population (2011) and 8 per cent of the seats in the national parliament. In that respect, as Adeney points out in this contribution, India's ethno-linguistic federation has been remarkably successful for 93 per cent of the population.

ii During the Constituent Assembly debates the hegemonic nationalist discourse played a major role in shaping minority rights. The partition of 1947 resulted in an overwhelming majority of Congress members in the Constituent Assembly, many of whom were upper caste, accounting for a quarter of the assembly while constituting only five per cent of the population. During the debate, a great deal of pressure was imposed on minority members to relinquish the reservation of seats that they had secured under the British. Muslims, demoralised by the departure of the Muslim League leadership to Pakistan and the violence of partition, had little choice but to disavow this reservation in the hope that the state might provide security to them. Since then, whereas the nature and scope of reservation of seats for Scheduled Castes (SCs) and Scheduled Tribes (STs) and the reservation of places in government employment for SCs and STs and the Other Backward Classes (OBCs) have been continuously extended, most notably after Mandal I and Mandal II, similar demands from religious minorities, the extension of cultural rights into socio-economic or political rights, remain constitutionally and politically difficult to negotiate.

iii Yiftachel classifies India as a consociational democracy, though with serious qualifications.

${ }^{\text {iv }}$ Although ethnic democracies share most features of liberal democracies for the included ethnic group, their relationship with excluded, peripheral and marginal ethnic groups is more problematic. At the extreme end of the continuum, ethnic democracies exercise coercive rule in which the 'superior power of one segment [dominant ethnic group] is mobilised to enforce stability by constraining the political action and opportunities of another segment or segments [subordinated ethnic group]' (Lustick 1979). In between these two extremes, an ethnic democracy might attempt to move towards a liberal democracy, or practise brute majoritarianism, thereby circumscribing the rights of marginal groups. In such a context, the main ethnic group 'can effectively dominate another segment (or segments) through its political, economic and ideological resources; and where this superordinate segment (or coalition of segments) can extract what it requires from the subordinated' (O'Leary and Authur 1990). This form of rule has been termed 'hegemonic control' because 'it makes an overtly violent segmental contest for state power either "unthinkable" or "unworkable" on the part of the subordinated segments' (ibid.). Thus, whereas 'violent control' resembles overt domination, suppression and open confrontation, 'hegemonic control' combines elements of coercion with some degree of consent that often underpins administrative structures.

${ }^{\mathrm{v}}$ This is clearly the case with SCs, and STs and such accommodation dates from the time of M. K. Gandhi. After 1947, some minorities, for example the Sikhs, had their collective rights revoked and were made subject to Hindu Personal Law. Article 25 of the constitution, moreover, defined the Sikhs (as well as Jains and Buddhists) as sects of Hinduism. Also, the criteria for SCs and OBCs were clearly defined by the overarching emphasis on caste within the Hindu tradition; and when this was challenged, the courts continued to err in favour of the hegemonic understanding of these categories. The Supreme Court held that 'the caste to which a Hindu belongs, is essentially determined by birth and that if a Hindu is converted to Christianity or another religion, which does not recognise caste, the conversion amounts to a loss of the said caste'. Mrs. S. Yasmine vs The Secretary on 13 June 2013. 
This is the accepted version of an article that will be published by Taylor \& Francis in Regional and Federal Studies: http://www.tandfonline.com/loi/frfs20

Accepted version downloaded from SOAS Research Online: http://eprints.soas.ac.uk/25494/

vi For a detailed consideration of these provisions, see articles 25-30, 15-16, 38, $350 \mathrm{~A}$ and B, 325, and 370 of the Indian Constitution.

vii The powers were allotted between three lists: the Central, the states and the Concurrent List. The centre predominates, and its decisions took precedence over matters included in the Concurrent List.

viii The capricious use of President's Rule which had become a tool to dismiss opposition governments in the states has been mitigated by the Supreme Court verdict in the S.R.Bommai v. Union of India case (1994) that now stipulates the conditions under such rule can be imposed. Most recently, President's Rule was imposed in Arunachal Pradesh (25 January-19 February 2016). In the 2014 state assembly election, despite the 'Modi wave', the Congress successfully formed the government in Arunachal Pradesh, winning 47 seats out of 60. After the formation of the government, the Governor, who had a close relationship with the BJP, made an allegation against the newly elected state government concerning financial mismanagement and malgovernance. This triggered the suspension of MLAs by the Speaker and the resignation of ministers from the state cabinet. Impeachment notices were submitted against the Deputy Speaker by 16 MLAs and a tribal community in the state (Nyishi), from which the Chief Minister of the state comes, condemning the Governor's actions as based on anti-minority sentiment. Claiming a complete collapse of law and order, the Governor requested the immediate imposition of President's Rule in the state, citing cow slaughter by tribals and the potential territorial dispute with China. Mithun (a local cow), and indigenous to the northeast, and traditionally used for a feast in public gathering of tribals, was projected by the Governor as the Hindu symbol of the holy cow, providing ideological grist to Hindutva to suppress minorities. Using the popular symbol, the centre promptly imposed President's Rule. Following criticism from Congress and other political parties about the misuse of Article 356, the centre justified its decision on the ground that the Chief Minister and Speaker of Arunachal Pradesh have provoked communal politics and the imposition of central rule was to protect the territory and sovereignty of the nation (Anand 2016; Prabhu and Phukan 2016; Singh and Hebbar 2016). The rational for President's Rule in this case was remarkably redolent of the Constituent Assembly Debates.

${ }^{\text {ix }}$ For turnout of regional party (-ies) in peripheral regions, see Statistical Reports of General Elections to State Legislative Assembly, Election Commission of India. Available at:

http://eci.nic.in/eci_main1/ElectionStatistics.aspx Accessed on 1 February 2016.

${ }^{x}$ There are, of course, exceptions to this. The peace accord with the Naga rebels in 2011 was followed by a more comprehensive accord in 2015 which has rehabilitated some of the former rebels. However, disagreements remains about the competing narratives of the accord and its ability to deliver (Singh 2016). 
This is the accepted version of an article that will be published by Taylor \& Francis in Regional and Federal Studies: http://www.tandfonline.com/loi/frfs20

Accepted version downloaded from SOAS Research Online: http://eprints.soas.ac.uk/25494/

\section{References}

Adeney, Katharine. 2002. 'Constitutional Centring: Nation Formation and Consociational Federalism in India and Pakistan'. Commonwealth \& Comparative Politics 40 (3): 833.

2007. Federalism and Ethnic Conflict Regulation in India and Pakistan. New York: Palgrave Macmillan.

2017. 'Does Ethnofederalism Explain the Success of Indian Federalism?' India Review 16 (1): 125-48.

Ahmed, Zubair. 2015. 'Why Is Punjab in Turmoil?’ BBC 30 October 2015.

Anand, Utkarsh. 2016. 'Governor J P Rajkhowa Cited "Cow Slaughter" protest as One Sign of Law and Order Collapse in State'. The Indian Express 28 January 2016.

Anderson, Perry. 2013. The Indian Ideology. London: Verso.

Austin, Granville. 1966. The Indian Constitution: Cornerstone of a Nation. Oxford: Clarendon Press.

Bajpai, Rochana. 2011. Debating Difference: Minority Rights and Liberal Democracy in India. Oxford: Oxford University Press.

Baruah, Sanjib. 2010. Ethnonationalism in India: A Reader. New Delhi: Oxford University Press.

Bhattacharyya, Harihar. 1999. Communism in Tripura. Delhi: Ajanta Publications.

- 2001. India as a Multicultural Federation: Asian Values, Democracy and Decentralisation (In Comparison with Swiss Federalism). Fribourg: Institute of Federalism.

. 2010. Federalism in Asia: India, Pakistan and Malaysia. London ; New York: Routledge.

2012. 'A Nation of Citizens in a Fragmented Society? Citizenship as Individual and Ethnic Entitlements in India'. In The Politics of Citizenship, Identity and the State in South Asia, edited by Harihar Bhattacharyya, Anja Kluge, and Lion König, 1-23.

New Delhi: Samskriti.

Bhaumik, Subir. 2015. "'Historic” Is Still Some Way Away'. The Hindu 27 August 2015.

Bose, Sumantra. 2003. Kashmir: Roots of Conflict, Paths to Peace. Cambridge, Mass.: Harvard University Press.

Brass, Paul R. 1974. Language, Religion and Politics in North India. Cambridge: Cambridge University Press.

1991. Ethnicity and Nationalism: Theory and Comparison. New Delhi: Sage.

Capoccia, Giovanni, Lawrence Sáez, and Eline de Rooij. 2012. 'When State Responses Fail: Religion and Secessionism in India 1952-2002'. The Journal of Politics 74 (4): 1010-22.

Chadda, Maya. 2000. Building Democracy in South Asia: India, Nepal, Pakistan. Boulder: Lynne Rienner Publishers.

Chima, Jugdep S. 2015. 'The Sikh "Political Prisoner" Issue and Hunger Strikes'. Sikh Formations 11 (3): 283-305.

Commission on Centre-State Relations. 1988. Commission on Centre-State Relations: Report. Part 1. Nasik: Government of India Press.

Das, Jogendra Kr. 2005. 'Assam: The Post-Colonial Political Developments'. The Indian Journal of Political Science 66 (4): 873-900.

Dhaliwal, Sarbjit. 2015. 'Debt to Cross Rs 1.2 Lakh Cr by Fiscal-End'. The Tribune 18 March 2015. 
This is the accepted version of an article that will be published by Taylor \& Francis in Regional and Federal Studies: http://www.tandfonline.com/loi/frfs20

Accepted version downloaded from SOAS Research Online: http://eprints.soas.ac.uk/25494/

Dhillon, K. S. 2006. Identity and Survival: Sikh Militancy in India 1978-1993. New Delhi: Penguin Books India.

Edkins, Jenny. 2003. Trauma and the Memory of Politics. Cambridge: Cambridge University Press.

Election Commission of India. Statistical reports of General Elections to State Legislative Assembly http://eci.nic.in/eci_main1/ElectionStatistics.aspx. Accessed 1 February 2016.

Embree, Ainslie T. 1990. Utopias in Conflict: Religion and Nationalism in Modern India. Berkeley, CA: University of California Press.

Franke, Marcus. 2009. War and Nationalism in South Asia: The Indian State and the Nagas. London: Routledge.

Gellner, Ernest. 2006. Nations and Nationalism. Oxford: Blackwell.

Government of India. 1984. White Paper on the Punjab Agitation. New Delhi.

Grewal, J. S. 1998. The Sikhs of the Punjab. Cambridge: Cambridge University Press.

Jaffrelot, Christophe. 1996. The Hindu Nationalist Movement in India. New York: Columbia University Press.

Jain, Bharti. 2015. 'Sacrilege, Khalistan on Sikh Convention Agenda?' The Times of India 31 October 2015.

Jeffrey, Robin. 1994. What's Happening to India?: Punjab, Ethnic Conflict, and the Test for Federalism. New York: Holmes \& Meier.

Johari, Aarefa. 2014. 'The Killings of Muslims in Assam Amounts to Ethnic Cleansing, Claims Report: A Report by the Indian American Muslim Council Says That Assam's Muslims Are Being Wrongfully Targeted as "Bangladeshis"”, Scroll.in 14 November 2014.

Khilnani, Sunil. 1998. The Idea of India. London: Penguin.

Kim, H. 2015. United Progressive Alliance (2004-14), Equality of Opportunity and Muslims: A Paradigm Shift or Political Pragmatism? PhD thesis, School of Oriental and African Studies, University of London.

Kohli, Atul. 2001. The Success of India's Democracy. Cambridge: Cambridge University Press.

Kumar, Ram Narayan. 2008. Terror in Punjab: Narratives, Knowledge, and Truth. Delhi: Shipra Publications.

Lacina, Bethany. 2015. 'Periphery versus Periphery: The Stakes of Separatist War'. The Journal of Politics 77 (3): 692-706.

Lustick, Ian. 1979. 'Stability in Deeply Divided Societies: Consociationalism versus Control'. World Politics 31 (3): 325-44.

Maxwell, Neville. 1972. India's China War. Harmondsworth: Penguin.

McGarry, John, and Brendan O'Leary, eds. 1993. The Politics of Ethnic Conflict Regulation: Case Studies of Protracted Ethnic Conflicts. London; New York: Routledge.

Mohapatra, Manas. 2004. 'Learning Lessons from India: The Recent History of Antiterrorist Legislation on the Subcontinent'. The Journal of Criminal Law and Criminology (1973-) 95 (1): 315-44.

Morris-Jones, Wyndraeth Humphreys. 1987. The Government and Politics of India. Huntingdon: Eothen Press.

Mrs. S. Yasmine vs The Secretary 13 June 2013.

Nandal, Randeep Singh. 2011. 'State Data Refutes Claim of 1 Lakh Killed in Kashmir'. The Times of India 20 June 2011.

Nayar, Baldev Raj. 1966. Minority Politics in the Punjab. Princeton: Princeton University Press. 
This is the accepted version of an article that will be published by Taylor \& Francis in Regional and Federal Studies: http://www.tandfonline.com/loi/frfs20

Accepted version downloaded from SOAS Research Online: http://eprints.soas.ac.uk/25494/

Nehru, Jawaharlal. 1989. The Discovery of India. New Delhi: Oxford University Press. Newbigin, Eleanor. 2013. The Hindu Family and the Emergence of Modern India: Law, Citizenship and Community. Cambridge: Cambridge University Press.

Nilanjan, Mukhopadhyay; 2015. 'Punjab Angry with Drug Abuse, Corruption, Lack of Governance and Misplaced Agricultural Policies'. Economic Times 31 October 2015.

O'Leary, Brendan. 2001. 'An Iron Law of Nationalism and Federation?: A (Neo-Diceyian) Theory of the Necessity of a Federal Staatsvolk, and of Consociational Rescue'. Nations and Nationalism 7 (3): 273-96.

O'Leary, Brendan, and Paul Authur. 1990. 'Introduction: Northern Ireland as the Site of State and Nation-Building Failures'. In The Future of Northern Ireland, edited by John McGarry and Brendan O'Leary, 1-47. Oxford: Clarendon.

Paul, G. S. 2015. 'Three Weeks Later, Akal Takht Revokes Pardon to Dera Chief'. The Tribune 16 October 2015.

Peled, Yoav. 1992. 'Ethnic Democracy and the Legal Construction of Citizenship: Arab Citizens of the Jewish State'. The American Political Science Review 86 (2): 432-43.

Pettigrew, Joyce. 1995. Sikhs of the Punjab: Unheard Voices of State and Guerilla Violence. London: Zed Books.

Prabhu, Sunil, and Sandeep Phukan. 2016. 'Why Arunachal Pradesh Governor Called For President's Rule'. NDTV 29 January 2016.

Ramesh, Vinayak. 1997. 'We Will Not Be Vindictive'. India Today 28 February 1997.

Smooha, Sammy. 1990. 'Minority Status in an Ethnic Democracy: The Status of the Arab Minority in Israel'. Ethnic and Racial Studies 13 (3): 389-413.

Sathyamurthy, T. V. 1997. 'Indian Nationalism: State of the Debate'. Economic and Political Weekly 32 (14): 715-21.

Shani, Giorgio.2008.Sikh Nationalism and Identity in a Global Age. New York: Routledge.

Singh, Ajay.2016. 'Nagaland accord is a botched deal: it promised 5,000 BSF jobs for NSCN cadre', Firstpost. 11 July.

Singh, A. P. K. 2009. Election Politics in Manipur. New Delhi: Mittal Publications.

Singh, Bikash. 2016. 'Mithun Reared as Meat Animal in Arunachal Pradesh and Other Northeastern States'. Economic Times 29 January 2016.

Singh, Gurharpal. 1991. 'The Punjab Problem in the 1990s: A Post-1984 Assessment'. The Journal of Commonwealth \& Comparative Politics 29 (2): 175-91. 2000. Ethnic Conflict in India: A Case-Study of Punjab. Basingstoke: Macmillan Press.

2001. 'The Limits of "Conventional Wisdom": Understanding Sikh EthnoNationalism'. In Sikh Religion, Culture and Ethnicity, edited by Arvind-pal Singh Mandair, Christopher. Shackle, and Gurharpal Singh, 142-60. Richmond, Surrey: Curzon.

2005. 'Managing the Anti-Corruption Rhetoric: The National Democratic Alliance, Transparency and Corruption'. In Coalition Politics and Hindu Nationalism, edited by Katharine Adeney and Lawrence Sáez, 136-52. London: Routledge. and Darshan Singh Tatla.2006. Sikhs in Britain: The Making of a Community. London: Zed Press.

2012 . 'Religious Transnationalism, Development and the Construction of Religious Boundaries: the Case of the Dera Sachkhand Ballan and the Ravidass Dharm'. Global Networks 13 (2): 183-199.

2017. 'Congress Landslide in Punjab or Back to the Future?'. IAPS Dialogue. Available at: https://iapsdialogue.org/2017/03/21/congress-landslide-in-punjab-orback-to-the-future/ 
This is the accepted version of an article that will be published by Taylor \& Francis in Regional and Federal Studies: http://www.tandfonline.com/loi/frfs20

Accepted version downloaded from SOAS Research Online: http://eprints.soas.ac.uk/25494/

Singh, Joginder. 2006. Myth and Reality of the Sikh Militancy in Punjab. New Delhi: Shree.

Singh, Vijaita, and Nistula Hebbar. 2016. 'Pranab Gives Assent to Central Rule in Arunachal Pradesh'. The Hindu 27 January 2016.

Smith, Anthony D. 1986. The Ethnic Origins of Nations. Oxford: Basil Blackwell.

S.R.Bommai v. Union of India 1994.

Suri, K. C. 2016. 'Andhra Pradesh: Political Dynamics of Regionalism, Formation of New States in India'. ISAS Working Papers 221: 1-32.

Swami, Praveen. 2014. 'Kashmir: Fewer Troops, More Peace'. The Hindu 21 January 2014.

Talbot, Ian, and Gurharpal Singh. 2009. The Partition of India. Cambridge: Cambridge University Press.

Thandi, S. S. 1996. 'Counterinsurgency and Political Violence in Punjab, 1980-94'. In Punjabi Identity: Continuity and Change, edited by Gurharpal Singh and Ian Talbot, 159-85. New Delhi: Manohar.

The Indian Express 2014. 'SAD-BJP Leads on 6, Aap 4, Cong 3 in Punjab', 16 May 2014. Tully, Mark, and Satish Jacob. 1985. Amritsar: Mrs Gandhi's Last Battle. London: Cape. Vanaik, Achin. 1997. The Furies of Indian Communalism: Religion, Modernity and Secularisation. London: Verso.

Wheare, Kenneth Clinton. 1946. Federal Government. London: Oxford University Press.

Yiftachel, Oren. 1992. 'Debate: The Concept of "ethnic Democracy" and its Applicability to the Case of Israel'. Ethnic and Racial Studies 15 (1): 125-36. 